\title{
'Out in the cold'?: The children of the Irish Parliamentary Party and the Irish Free State
}

\author{
JAMEs MCCONNEL* \\ Northumbria University
}

\begin{abstract}
Drawing on the recent scholarly interest in 'generationism' and the revolutionary period, this article examines the life chances of the 247 children born to the last cohort of Irish Parliamentary Party M.P.s elected to Westminster between 1910 and 1918. It employs a prosopographical approach to reconstruct their lives at specific points (1910 and 1948 ) in order to assess the impact that independence had on their fortunes longitudinally. While it problematises the idea that the Edwardian children of nationalist M.P.s formed part of a privileged elite in waiting, it does conclude that they enjoyed a degree of cultural and political capital that positioned them advantageously in advance of home rule. The analysis advanced here suggests that despite experiencing some political disorientation, those scions of the old I.P.P. who lived through the revolutionary years reoriented themselves relatively quickly, regrouped, and experienced considerable political and professional success during the following decades. As for those children who were born or achieved adulthood after 1922, there is little evidence to suggest that they were socially or politically ostracised, or that, in turn, they felt a sense of fundamental alienation from the new state. Ultimately, unlike those who had fought for the republic but ended up feeling as if they were among the losers, what the children of the I.P.P lost after 1918 should not obscure the fact that many of them were among the winners in the new Ireland.
\end{abstract}

$\mathrm{I}$ n his 1998 memoir, Conor Cruise O'Brien wrote that before 1918, when John Redmond's Irish Parliamentary Party (I.P.P.) seemed to be on the verge of securing self-government for Ireland, his grandfather, David Sheehy, M.P. (South Meath), had been a 'person of considerable consequence', since he was 'one of the senior members of the party'. O'Brien believed that had home rule been achieved, his grandfather 'would certainly have had a seat in the Irish cabinet'. Indeed, his 'whole family would have been part of the establishment of the new Home Rule Ireland'. But owing to Sinn Féin's rise after 1916, 'we were out in the cold, superseded by a new republican elite'. Whereas before 1918, 'To be connected with the Irish Parliamentary Party had been an asset; it was now a liability.,

\footnotetext{
* Department of Humanities, Northumbria University, james.mcconnel@northumbria.ac.uk
}

${ }^{1}$ Conor Cruise O’Brien, Memoir: my life and themes (London, 1998), pp 20-21. 
A conversation of the late 1960s between O'Brien and his father-in-law, the 1916 veteran, I.R.A. commander and Fianna Fáil T.D., Seán MacEntee, exemplifies O'Brien's feelings of entitlement and dispossession:

O'Brien ... provoked McEntee with a sweeping statement: '1916 was a mistake'. Seán MacEntee replied, 'Maybe it was, but I am glad I was part of it.' McEntee's daughter, Maureen [sic] added with superb clear-sightedness, 'Conor, your grandfather was a member of the Irish Parliamentary Party. You were part of the elite. My father was the son of a publican. He would never have become minister without 1916 . He would never have had a fine house, his children would never have been to the best schools.' Ruefully, Conor Cruise O'Brien answered, 'Exactly, your people pushed mine aside.'

Of course, O'Brien's sense of displacement could also be attributed to his own ego and ambition. After all, notwithstanding all his supposed disadvantages, O'Brien still managed to become a senior diplomat, government minister, and public intellectual in the country established by McEntee's generation, while O'Brien's uncle, Eugene Sheehy, had become a Free State judge, with O'Brien's aunt, Hanna Sheehy Skeffington, serving in the Dáil courts, helping to co-found Fianna Fáil, and acting as one of Ireland's leading feminist activists. Indeed, as one scholar has observed, 'they were in their own way scions of the new regime'. Nonetheless, for someone like Eugene and Hanna's sister Mary (like them the child of an M.P. but also the wife of one), she still believed that 'her ... family had come down in the world' after 1918. ${ }^{3}$

In recent years, historians have begun to reassess the fortunes of the 'winners' and 'losers' of the Irish Revolution. ${ }^{4}$ The perception that the personnel of the I.P.P. (and by implication the people associated with them) were among those worsted in the game remains unchallenged, however. ${ }^{5}$ This article seeks to go beyond Sheehy family folklore by testing O'Brien's claim that those with 'what Irish republicans ... used to call "the bad parliamentary drop [of blood in their veins]" not only lost out as a result of Irish independence but also found independent Ireland something of a cold house. ${ }^{6}$ In order to do so it adopts a prosopographical approach for a specific and definable group: the children of those M.P.s elected to parliament between 1910 and 1918. It attempts to reconstruct their life chances at specific points (1910 and 1948) in order to assess the impact that independence had on their fortunes. In doing so, this article seeks to contribute to the emerging scholarly literature that uses the concept of 'generationism' to understand early twentieth-century Irish history.

2 Irish Times, 23 July 1994.

3 Diarmuid Whelan, Conor Cruise O'Brien: violent notions (Dublin, 2009), p. 11; Conor Cruise O’Brien, States of Ireland (London, 1972), p. 106.

${ }^{4}$ For example, see David Fitzpatrick, 'Protestant depopulation and the Irish Revolution' in I.H.S., xxxviii, no. 152 (Nov. 2013), pp 643-59; Roy Foster, Vivid faces: the revolutionary generation in Ireland, 1890-1923 (London, 2014); Paul Taylor, Heroes or traitors? Experiences of southern Irish soldiers returning from the Great War, 1919-1939 (Liverpool, 2015).

${ }^{5}$ For example, see Dermot Meleady, Redmond: the Parnellite (Cork, 2008); Chris Dooley, Redmond: a life undone (Dublin, 2015).

${ }^{6}$ O'Brien, Memoir, p. 8.

7 See Foster, Vivid faces, p. 7; Caoimhe Nic Dháibhéid, "Fighting their fathers": the post-revolutionary generation in an independent Ireland' in Senia Pašeta (ed.), Uncertain futures: essays about the Irish past for Roy Foster (Oxford, 2016), pp 148-60. 
The dataset on which this research draws includes information on the 247 children known to have been born to the eighty-nine nationalist M.P.s elected between 1910 and 1918 (60 per cent of whom had offspring). Using the 1901 and 1911 censuses, newspapers, private papers, memoirs, biographies, autobiographies, and other sources, data for these 247 children have been analysed for this article. ${ }^{8}$ Inevitably, these data are not complete, as detailed information is not available for all the children to the same extent. In particular, data for M.P.s' daughters (especially relating to their occupations) are incomplete. The obstacles faced by women entering and remaining in the labour force in this period, the social norm of women giving up work after marriage, and the custom of changing surname following marriage make the data for I.P.P. M.P.s' daughters particularly fragmentary. Additionally, the small number of memoirs and archives produced by M.P.s' children inevitably privileges certain voices.

The fortunes of the I.P.P. children before, during, and after the revolutionary period provide a particularly interesting case study because, unlike other displaced political elites (of France in 1789, Russia in 1917, or Cuba in 1959, for example), Irish parliamentary nationalists did not go into exile as a result of the I. P.P.'s defeat. ${ }^{9}$ Because the home rule elite was displaced by a parliamentary process, not a violent coup, the politics of their children were not conditioned by the experience of significant violence, physical exile, or the ambition to restore an exiled leader. As a result, there were no second-generation exiles to ferment counter-revolutionary activity from abroad. ${ }^{10}$ Instead, the children of the displaced home rule elite remained in Ireland and so had to accommodate themselves to the new regime after 1922 more swiftly and more fully perhaps than other comparable groups in modern history.

In assessing the fortunes of the children of I.P.P. M.P.s, this article rejects the assumption that those who had reached adulthood before 1918 constituted some form of home rule Brahminate. By drawing on two recent contributions to the study of Edwardian Irish elites, it is clear that the socio-economic profile of these I.P.P. children did not place them among either Fergus Campbell's Irish 'establishment' or Ciaran O'Neill's 'Catholics of consequence'. ${ }^{11}$ On the other hand, the pre-war adult cohort did share certain common formative experiences (such as growing up in political households) and these undoubtedly provided them with certain life advantages. Before 1918, I.P.P. children enjoyed a form of inherited political capital derived from a

${ }^{8}$ The existence of M.P.s' offspring was established using newspaper obituaries and funeral reports for their parents; in particular, the Irish Newspaper Archive (www.irish newsarchive.com), the online Irish Times archive (www.irishtimes.com/archive), the British Library's British Newspaper Archive (www.britishnewspaperarchive.co.uk), and other digitised press titles were used. These were supplemented by use of the 1901 and 1911 censuses for Ireland and Britain. Other biographical data were collected using records available on Ancestry (www.ancestry.co.uk), FamilySearch (www.familysearch. org), the Dictionary of Irish Biography and the Oxford Dictionary of National Biography.

'On this see Yossie Shain, The frontier of loyalty: political exiles in the age of the nation-state (Ann Arbor, MI, 2005).

${ }^{10}$ For example, see Sebastiaan Faber, Exile and cultural hegemony: Spanish intellectuals in Mexico, 1929-1975 (Nashville, TN, 2002), p. 162.

${ }^{11}$ Fergus Campbell, The Irish establishment, 1879-1914 (Oxford, 2009); Ciaran O'Neill, Catholics of consequence: transnational education, social mobility, and the Irish Catholic elite, 1850-1900 (Oxford, 2014). 
combination of their fathers' status as M.P.s in British Ireland and their projected future standing as members of the future home rule parliament. In addition, some children benefited from privileged access to political networks and to insider knowledge. While only a small number belonged to the younger generation of Edwardian home rulers whom Senia Pašeta has described as being 'poised to inherit the free and sovereign Ireland which seemed at last to be within reach', the outbreak of the war in 1914 suggests that critics of the I.P.P. saw the children of the party as sharing in the political sins of their fathers. ${ }^{12}$ As such, if they were not viewed as a discrete group, they were clearly seen as auxiliaries of the I.P.P.

In its findings, this article compliments recent unpublished research on Irish politics after 1922. Martin O'Donoghue's 2016 doctoral thesis analyses the 'influence and persistence of Irish Party individuals, organisations and political culture in independent Ireland', highlighting 'the persistence of home rule loyalty in the Free State and the effects this had on the development of party politics' ${ }^{13}$ The analysis advanced here suggests that despite experiencing feelings of loss and displacement after 1918 (which undoubtedly persisted in some cases for decades), those scions of the old I.P.P. who lived through the years of turbulence between 1916 and 1923 re-oriented themselves relatively quickly, regrouped, and experienced considerable success under the new regime. As for those children who were born or achieved adulthood after 1922, there is very little evidence to suggest that they were socially or politically ostracised, or that, in turn, they felt a sense of fundamental alienation from the new state. In short, the available evidence does not suggest that the life chances of these children were adversely affected by independence to a measurable extent.

Whether born before or after 1922, the success of the I.P.P. children in the professions, in business, in government service, and in civil society demonstrates the importance of the relatively high social, cultural, and political capital they inherited, which in many cases allowed them to weather the revolutionary and post-revolutionary years relatively unscathed. Crucially, whatever hostility existed towards their fathers before 1918 was eclipsed by the much greater levels of animosity between the two Civil War sides. The fluidity of post-civil war Irish politics provided opportunities for a significant number of I.P.P. children to adapt and even shape parliamentary politics in ways often disproportionate to their numbers. In this, they were helped by cultural factors such as the primacy of politics over violence after 1922 and the structural similarities of the new state to its predecessor. ${ }^{14}$ As a result, while it would be inaccurate to see these men and women as Reganite counter-revolutionaries, the success of the I.P.P. children in southern Ireland after 1922 arguably contributed to the conservatism of the state that had supplanted the home rule Ireland their fathers had endeavoured to establish. ${ }^{15}$

12 Senia Pašeta, Before the revolution: nationalism, social change, and the Catholic elite, 1879-1922 (Cork, 1999), p. 1.

${ }^{13}$ Thomas Martin O’Donoghue, 'The legacy of the Irish Parliamentary Party in independent Ireland, 1922-49' (Ph.D. thesis, National University Ireland, Galway, 2016), p. i.

${ }^{14}$ John M. Regan, The Irish counter-revolution, 1921-1936: treatyite politics and settlement in independent Ireland (Dublin, 1999).

15 Regan, The Irish counter-revolution. 
James Joyce's character, Mr Doyle senior, who appears in 'After the race', was allegedly based on the real-life Edwardian nationalist William Field, M.P. (Dublin, St Patrick's). ${ }^{16}$ Described as one who had 'begun life as an advanced Nationalist', Doyle has long since 'buried' or 'modified' his political views for business advantage and social advancement. 'After the race' focuses on Doyle's son Jimmy, whose expensive education at a 'big Catholic college' in England, followed by Trinity College Dublin and then Cambridge University, is seen by his father as a sound 'commercial' investment, 'having secured for his son [social] qualities often unpurchaseable'. Indeed, Doyle senior is 'remonstrative, but covertly proud' of the fact that Jimmy has only a dim awareness 'of the labour latent in money'. As the story unfolds, it becomes clear, however, that Jimmy's new friends among the fast set have only befriended him because his social anxiety fuels a profligacy that directly benefits them. ${ }^{17}$

In real life, Field was a bachelor who lived with his spinster sister. Nonetheless, Joyce's presentation of Doyle senior is consistent with his (and other critics') non-fictional characterisation of nationalist M.P.s as men who had done little but 'improve their own lot'. ${ }^{18}$ Historians differ as to how far election to parliament accelerated the intra-generational social mobility of Irish nationalist M.P.s (i.e. the extent to which they experienced changes in their social situations over the course of their lives), though the late Alan O'Day argued that 'a good measure of upward social mobility was in progress' among Parnell's party. ${ }^{19}$ Patrick Maume has observed that the Edwardian I.P.P. (which included a considerable number of old Parnellites) became more politically conservative as M.P.s aged, 'achieved professional success or inherited family businesses, and acquired family responsibilities'. ${ }^{20}$ The perception that nationalist M.P.s were men on the make arguably coloured how Joyce saw the life opportunities available to the children of the I.P.P.

Joyce's picture of Doyle junior's ambitions and life opportunities may have drawn some inspiration from a number of his own friends. Via school and university networks, Joyce was friendly with the children of the Meath M.P. David Sheehy and attendance at the regular salons at Sheehy's Dublin home provided one of various avenues through which Joyce came into contact with Edwardian Ireland's aspirant Catholic middle class. After abandoning his plans to enter the priesthood, Sheehy had become a mill owner, while in politics he became successively a Fenian, Land War activist, and then a nationalist M.P. Although there was 'never much money in the Sheehy

${ }^{16}$ Allan H. Simmons, 'Topography and transformation: a postcolonial reading of Dubliners' in Leonard Orr (ed.), Joyce, imperialism, and postcolonialism (Syracuse, NY, 2008), p. 24.

${ }^{17}$ James Joyce, Dubliners, ed. Jeri Johnson (Oxford, 2000; first published 1914), pp 30-35.

${ }^{18}$ Il Piccolo della Sera, 19 May 1907; James McConnel, The Irish Parliamentary Party and the third home rule crisis (Dublin, 2013), pp 11-15.

${ }^{19}$ Alan O'Day, The English face of Irish nationalism: Irish involvement in British politics, 1880-86 (Dublin, 1977), p. 22. However, see Conor Cruise O’Brien, Parnell and his party, 1880-90 (Oxford, 1957), pp 17-18.

${ }^{20}$ Patrick Maume, The long gestation: Irish nationalist life, 1891-1918 (Dublin, 1999), p. 36 . 
household', the family possessed that 'patina of gentility which went with professionalism'; combined with a strong patriotic record, this made for a certain kind of nationalist respectability. ${ }^{21}$ Unlike Jimmy Doyle, however, Sheehy's sons Eugene and Dick Sheehy attended 'not the grandest public schools ... but ... the next best', Belvedere College, where they played rugby. ${ }^{22}$ Later, they attended University College. Sheehy's daughters, Margaret, Hanna, Mary, and Kathleen, all attended the Dominican Convent on Eccles Street, Dublin, with the last three also taking degrees from the Royal University. The two brothers eventually became barristers, with Hanna becoming a teacher and feminist, Margaret an amateur dramatist (before marriage to a wealthy solicitor in 1907), Kathleen an Irish language teacher, and Mary a teacher and suffrage campaigner (before she married Tom Kettle, M.P. (East Tyrone), in 1909).

Among the 161 children of I.P.P. M.P.s alive by 1910 (65 per cent of all the children under consideration in this article), the experiences of the Sheehy children were unusual, if not unique. If few I.P.P. children enjoyed the kind of transnational education ascribed to Jimmy Doyle and explored recently by O'Neill in his study of elite Irish Catholic education, only 11 (or 13 per cent) of M.P.s' sons alive by 1910 (of whom there were 84 in total) had or were being educated at one of the elite Irish Catholic schools. Equivalent figures for their fathers do not exist, though according to Campbell 12 per cent of the I.P.P. in 1911 had been educated at Clongowes. ${ }^{23}$ The figure for the sons of I.P.P. M.P.s attending elite Irish Catholic schools is much smaller than those for two key (albeit older) Catholic groups among Campbell's Irish 'establishment': senior Irish civil servants ( 25 per cent) and the Irish business elite ( 21 per cent $){ }^{24}$ That six of the eleven Edwardian sons of I.P.P. M.P.s who had attended an elite school had the same father (Patrick A. Meehan, M.P. for Queen's County) further underlines how unusual such an education was for this cohort. Instead, the great majority of the children alive by 1910 had or were receiving a secondary education in one of Ireland's national schools, something that two-thirds of all Irish children enjoyed by 1911.

O'Neill notes that an elite higher education was regarded as a 'desirable goal for the aspiring middle class' in Catholic Ireland in this period. ${ }^{25}$ Campbell estimates that something like 1,000 Catholics per year were graduating from Ireland's various higher education institutions from the 1880s onwards, which would suggest a 'pool' of perhaps 30,000 Catholic graduates by 1910, or something like 3.3 per cent of those Catholic men and women (aged 20 to 49 in 1911) who could have attended in this period. ${ }^{26}$ Among the seventy-five children of M.P.s aged eighteen or over by 1910 for whom data exist, eight (11 per cent) had or were receiving a third-level education (mostly in Ireland,

${ }^{21}$ Leah Levenson and Jerry H. Natterstad, Hanna Sheehy Skeffington: Irish feminist (Syracuse, NY, 1986), p. 7; O'Brien, States of Ireland, p. 80.

${ }_{22}$ O'Brien, States of Ireland, p. 62.

23 Campbell, The Irish establishment, p. 174.

24 Ibid., pp 67, 213-14.

${ }^{25}$ O'Neill, Catholics of consequence, p. 2.

${ }^{26}$ Campbell, The Irish establishment, pp 77-9. The 1911 census details 1,246,706 men and women aged 20 to 49 . Catholics constituted 73.8 per cent of the Irish population, suggesting that the Catholic portion of those aged 20 to 49 was roughly 920,069. 30,000 is 3.3 per cent of this figure. 
though only one at Trinity). That five of this group were the children of David Sheehy underlines, however, how unusual a third-level education was among I.P.P. children.

Among the twenty-two M.P.s who had fathered adult children by 1910 , fifteen (or 68 per cent) had not been to university themselves; eleven of these fifteen can be classified as falling into the 'lower middle class' occupational category (e.g. local merchants, farmers, tenant farmers, labour leaders, etc.) used by F. S. L. Lyons in his classic 1951 study of the I.P.P. ${ }^{27}$ These eleven $^{2}$ M.P.s accounted for 68 per cent (fifty-one people in total) of the seventy-five children who had reached the age of eighteen by 1910, 98 per cent of whom had not received a university education. This would suggest that a combination of parental experience and family income explains why so few M.P.s' adult children had attended university by 1910 . That said, the fact that a degree was not necessary for a number of professional careers in Edwardian Ireland was probably also a consideration for families assessing the costs and benefits of university attendance.

The educational profile of the children of late Edwardian M.P.s suggests that if attendance at elite schools and universities were cultural markers of Edwardian Ireland's aspirational Catholic middle class, then many home rule M.P.s and their children were seemingly on its fringes. That M.P.s nonetheless shared the same anxieties as many other ambitious Catholic parents (that Ireland was over-producing professionals, relative to jobs, and that institutional prejudice continued to favour Irish Protestants) is suggested by their behaviour. Patronage was seen to be essential in securing positions in Edwardian Ireland and those considered influential were frequently asked to intervene on behalf of candidates applying for official appointments and promotions. In this regard, nationalist M.P.s were themselves seen as among those with influence. ${ }^{28}$ While their influence was most often used on behalf of constituents and political allies, some M.P.s did seek to help their own children. William Lundon, M.P. (East Limerick), wrote to John Dillon in 1908 asking him to help his son, Thomas, secure appointment as a government inspector, while John Roche, M.P. (East Galway), asked Dillon in 1912 to help his son, James, secure promotion within the Irish civil service. ${ }^{29}$ In one instance, a nationalist M.P. was even apparently willing to exert influence publicly on his child's behalf. When Matthew O'Dowd was appointed as the accountant to Sligo County Council in 1912, the councillors made much reference to 'the merits of his father' (John O'Dowd), who was the M.P. for South Sligo and also the person chairing the meeting in his other capacity as chairman of the council! ${ }^{30}$ Such a public display of influence was unusual (M.P.s preferred to avoid drawing attention to so-called 'placehunting'), but it highlights the single-mindedness of some M.P.s in advancing their children's interests.

Of course, such parental ambition was not confined to M.P.s' sons alone. The development of Catholic education specifically for middle-class girls and women in this period meant that the horizons of at least some M.P.s' daughters

27 F. S. L. Lyons, The Irish Parliamentary Party, 1890-1910 (London, 1951), pp $169-76$.

${ }_{28}$ McConnel, The Irish Parliamentary Party, pp 71-93.

29 William Lundon to John Dillon, 7 Apr. 1908 (T.C.D., John Dillon papers, MS 6756/924); John Roche to John Dillon, 3 June 1912 (Ibid., MS 6750/109).

30 Western People, 20 July 1912. 
were also broadening. ${ }^{31}$ David Sheehy's daughters were not unique, with the daughters of a number of I.P.P. members being educated privately by nuns. ${ }^{32}$ For a small number of M.P.s' daughters, their educational advantages facilitated access to the new professional opportunities that were opening up for middle-class Irish women. One of the daughters of the North Longford M.P., J. P. Farrell, Mary, was, for example, among the pioneering group of Irishwomen who became medical doctors at the start of the twentieth century. ${ }^{33}$ Even for daughters without such educational advantages, there were still opportunities: Mary Condon (daughter of Tom Condon, M.P. (East Tipperary)) was a 'renowned' singer on both sides of the Irish Sea before the First World War. ${ }^{34}$

In the case of some daughters (and sons as well), another strategy for social reproduction and/or upward mobility pursued by their parents was marriage. If the marriage strategies adopted by these families did not centre around 'the jaded faux-grandeur of the Castle season' like the elite Catholics O'Neill has studied, marriage was nonetheless considered to be an important factor in influencing life chances. ${ }^{35}$ Mary Sheehy's mother approved of her daughter's fiancé Tom Kettle because, as her grandson later noted, '[while] Bessie did not know words like "upward social mobility" and "rising national bourgeoisie", she nonetheless 'intended, quite consciously I believe, to preside over the birth of a new ruling class: those who would run the country when Home Rule was won'. ${ }^{36}$ While here (as elsewhere) it would be unwise to generalise from the experiences of the Sheehys, sociological analysis suggests that the 'social location' of a groom or bride was 'important in determining at what social level' they could marry in this period. ${ }^{37}$ Something similar may have been a consideration when it came to John Redmond's daughters. As a young 'squireen' of limited means (he was the first son of a second son), Redmond's own first marriage had been an advantageous one to a member of a prosperous family of an Irish-Australian immigrant. ${ }^{38}$ Later, in 1913, Redmond's daughter Johanna married Max Green; in Green, Redmond acquired a Trinity-educated son-in-law who was chairman of the Irish Prisons Board. While this may have been a source of political embarrassment later on, in 1913 Green 'typified the generation of young nationalists taking up important posts in the Irish administration as the momentum for home rule grew'. ${ }^{39}$ That Green's immediate family included two Trinity-educated brothers (one a senior British army officer and the other a county court judge) underlines

${ }^{31}$ Caitriona Clear, Social change and everyday life in Ireland, 1850-1922 (Manchester, 2007), pp 43-5, 48-50.

32 J. Anthony Gaughan, A political odyssey: Thomas O'Donnell, M.P. for West Kerry, 1900-1918 (Dublin, 1983), p. 141; Dermot Meleady, John Redmond: the national leader (Sallins, Co. Kildare, 2014), p. 12; Longford Leader, 16 Sept. 1919.

33 Longford Leader, 6 Sept. 1916.

34 Irish Examiner, 30 July 1913.

${ }^{35}$ O'Neill, Catholics of consequence, p. 164.

${ }^{36}$ O'Brien, States of Ireland, pp 62-3.

37 Kenneth Prandy and Wendy Bottero, 'Social reproduction and mobility in Britain and Ireland in the nineteenth and early twentieth centuries' in Sociology, xxxiv, no. 2 (May, 2000), p. 272.

38 Meleady, Redmond, p. 72.

39 Ibid., p. 229. 
the way that intermarriage enmeshed some M.P.s into wider middle-class Catholic networks. ${ }^{40}$

Among provincial M.P.s, the alliances and networks formed through the marriage of children were doubtless also of importance. For example, the daughter of the merchant John Fitzgibbon, M.P. (South Mayo), Henrietta, married the prominent Kilkenny merchant Richard Duggan in 1900; Duggan had been 'repeatedly urged to become a member of the Irish Parliamentary Party, but his extensive business left him no time for politics' ${ }^{41}$ Occupational data exists for twelve of the thirteen men who had married M.P.s' adult daughters by 1910: five had occupations that correspond to Lyons's 'lower middle class' occupational category. Like Duggan, two of these husbands were merchants and this highlights the way that Lyons's categorisation underplays the local importance of rural Ireland's merchants and strong farmers. Seven of the thirteen husbands had jobs that correspond with Lyons's 'upper middle class' category (e.g. civil servants, architects, doctors, etc.).

Taken alongside the evidence for educational and marital strategies, the available occupational data for those working age male and female children born by 1910 tells an interesting, if complex, story about the I.P.P. vis-à-vis Edwardian Ireland's aspiring Catholic middle class. ${ }^{42}$ Evidence exists to show that 22 M.P.s had fathered 75 children aged 18 years or older by 1910 . Occupational data exists for 37 of these sons and daughters (49 per cent of the 75). Analysis suggests that 17 of the 37 (46 per cent) had jobs in 1910 that correspond to Lyons's 'upper middle class' category; the equivalent figure for the I.P.P. itself in 1910 being 45 per cent. The composition of these two groups very much reflected, however, generational differences. Whereas 37 per cent of I.P.P. M.P.s were lawyers, only 10 per cent of the children of the I.P.P. practised law by 1910 . Aside from the three who were Catholic religious, the professions were not especially well represented among those children in the 'upper middle class' category, as this group included an eclectic mix of elocutionists, translators, playwrights, and social and political activists. Journalists were also conspicuous by their relative absence (only two sons worked for the press). As for those whom Lyons categorised as 'lower middle class', the most significant groups were farmers' children (22 per cent) and merchants' children ( 8 per cent), reflecting the fact that these two categories taken together accounted for 29 per cent of nationalist M.P.s in $1910 .{ }^{43}$ That two-thirds of the M.P. fathers in 1910 had 'lower middle class' occupational profiles and that these men accounted for three-quarters of the working-age children born by this date is also suggestive.

Given this profile, it is difficult to see these children as core members of Campbell's 'establishment' of British Ireland. That they did not constitute some form of nationalist Brahminate is further suggested by how few of them secured employment in the service of the British state and empire before 1914. While service to the British government in Ireland seems to have been deemed acceptable by some (Eugene Sheehy was briefly a civil servant in Ireland before being called to the bar in 1910), the only child of an M.P. who appears to have held an official position within the British Empire was Eugene's brother,

40 Irish Examiner, 4 Mar. 1922.

41 Irish Independent, 3 June 1933.

${ }^{42}$ Regan, The Irish counter-revolution, p. 245.

43 Lyons, The Irish Parliamentary Party, p. 169. 
Richard, who was 'a legal adviser to the governor of St Kitts, in the West Indies'. ${ }^{44}$ Once again, this underlines the aberrant nature of Conor Cruise O'Brien's family, since among the other I.P.P. children who had reached adulthood before the war, the only other child with a known imperial connection was the son of William Abraham, M.P. (Dublin Harbour constituency), William L. Abraham, who was in the 'East India trade' ${ }^{45}$

It is possible that this pattern may have reflected underlying nationalist sensitivities; though the Sheehys' self-congratulation on boycotting Edward VII's visit to Ireland in 1903 clearly did not prevent the sons of the family from serving Dublin Castle or the empire. Other children were even less backwards in coming forwards; Edward Meehan (the third son of the M.P. for the Leix division of Queen's County) was among those pupils who welcomed Queen Victoria when she visited Castleknock College in $1900 .{ }^{46}$ As such, while the fact that no children were employed as soldiers or policemen in Ireland or elsewhere in the empire in 1910 may reflect the operation of a self-denying ordinance, financial means, educational attainment, and the right sort of connections were probably just as important.

Taken as a whole then, these data suggest that in terms of social reproduction, Edwardian M.P.s and their children reflected the more general trend in the long nineteenth century that 'social transmission from the father to the son' was important in influencing the latter's 'early career position' ${ }^{47}$ The available data for M.P.s' children are suggestive more of a scenario in which they inherited their family's social position (inter-generational mobility), as opposed to one in which they had experienced a significant change in their social situation over the course of their relatively short lives (intra-generational mobility). Very few Edwardian M.P.s were independently wealthy (Lyons estimates that 'a minimum' of 50 per cent of the I.P.P. between 1906 and 1910 was receiving financial support from the party's Parliamentary Fund). ${ }^{48}$ Fees for elite schools and universities were expensive and entry costs to the higher professions were often costlier and more time-intensive than joining a family business or working on a family farm. Moreover, while election to parliament provided M.P.s (and to a lesser extent their children) with political capital, this was a function of party allegiance; wealth was neither a prerequisite nor a necessary consequence of sitting at Westminster. Few M.P.s' children were born into 'metropolitan new money or predestined for a life as ... comfortable country squire[s]'; their educations and occupations suggest that they were not 'Catholics of consequence' as historians have recently defined this stratum.

\section{II}

While the adult children of Edwardian nationalist M.P.s did not come from especially wealthy backgrounds, they nonetheless could be said to have promising futures by virtue of their relationship to the home rule elitein-waiting, since by 1912 Irish self-government was keenly anticipated.

46 Whelan, Conor Cruise O'Brien, p. 12; Philip Sheppard, 'Protestant society and nationalist popular politics: the Queen's County, 1898-1914' (M.Phil., Newcastle University, 2017), p. 50.

47 Prandy and Bottero, 'Social reproduction and mobility', p. 273.

48 Lyons, The Irish Parliamentary Party, p. 210. 
The Sheehy children's social ambition was certainly inseparable from their desire 'to play an important role in the new Ireland' that they believed would be created when an Irish parliament was re-established in Dublin. ${ }^{49}$ Like many other children of I.P.P. members, they had grown up in political households in which their fathers' colleagues were often visitors, they themselves visited the houses of parliament, and they participated in mock parliamentary debates at home. $^{50}$ John Dillon's sons certainly practised their oratory at home in preparation for the day when [t]he[y] would be called upon to address the "House", 51 Likewise, the daughter of J. P. Boland (M.P. for South Kerry), Bridget, recalled that her father 'loved debate, and encouraged all of us to enjoy the art of argument'. ${ }^{52}$ The Sheehy brothers and sisters were prominent members of University College's Historical Debating Society before the war, in which "[a] "British House of Commons" atmosphere during debates underlined the significance of their discussions. For participants, the L\&H was a small parliament and a model of the national parliament they might one day participate in. ${ }^{53}$ As Frank Aiken put it many years later, people like James Dillon had been 'trained to sit, act and talk in another assembly'. ${ }^{54}$

Patricia Lavelle (daughter of the South Kilkenny M.P. James O’Mara) recalled that 'Dad lived ... at the hub of political life and we, as little children, were drawn into the vortex. ${ }^{, 55}$ Lavelle remembered tours of Westminster and that '[b]efore we went to kindergarten we were Home Rulers'. ${ }^{56}$ Similar experiences doubtless prompted some of the I.P.P. children who were old enough before 1914 to become politically active. The North Dublin M.P. J. J. Clancy's son, Charles Parnell Clancy, was, for example, an active grassroots campaigner in the nationalist interest during the 1910 general elections. ${ }^{57}$ T. J. Condon's son Jerome attended political meetings and I.P.P. funerals. ${ }^{58}$ Three M.P.s' sons joined the I.P.P. between 1909 and 1913, including John Redmond's son William as M.P. for East Tyrone (having been taken to I.P.P. meetings as a boy by his father). ${ }^{59}$ Several of the Sheehy children (as well as their current or soon-to-be spouses) were closely involved in setting up the Young Ireland Branch (Y.I.B.) of the United Irish League (the constituency organisation of the I.P.P.). ${ }^{60}$ In part because of his prominence as a Y.I.B. activist, Mary Sheehy's husband, Tom Kettle, became a nationalist M.P., while by 1913-14 her brother Eugene was also being groomed for a parliamentary career. ${ }^{61}$ That said, the Y.I.B. was also critical of the party:

49 Margaret Ward, Hanna Sheehy Skeffington: a life (Cork, 1997), p. 1. See also Donald Harman Akenson, Conor: a biography of Conor Cruise O'Brien (2 vols, Montreal, 1994), i, 13.

50 Ward, Hanna Sheehy Skeffington, p. 8; Maura Brock to Colonel Josiah Wedgewood, 7 Jan. 1937 (History of Parliament Trust, London, Wedgewood Archive).

51 Regan, The Irish counter-revolution, p. 342.

52 Bridget Boland, At my mother's knee (London, 1978), p. 45.

53 Pašeta, Before the revolution, p. 64.

54 Maurice Manning, James Dillon: a biography (Dublin, 1999), p. 108.

55 O'Mara resigned from the I.P.P. in 1907.

56 Patricia Lavelle, James O'Mara: a staunch Sinn Feiner (Dublin, 1961), pp 141-2.

57 Freeman's Journal, 10 Dec. 1910.

58 Ibid., 1 Aug. 1899, 1 June 1906.

59 Information on Redmond provided by Honor Ó Brolcháin to author, 8 Aug. 2016.

${ }^{60}$ Ward, Hanna Sheehy Skeffington, pp 25-6.

61 Freeman's Journal, 14 Apr. 1913, 22 Apr. 1914. 
Richard Sheehy and his brother-in-law Frank Sheehy Skeffington (husband of Hanna) were among those who openly criticised the party's alliance with the Liberals, advocating instead a more independent policy. ${ }^{62}$ Hanna herself, of course, became a vociferous feminist (and later republican) critic of the I.P.P., though her family background and father's political status were nonetheless important to her political trajectory. Such dynasticism prefigured that of Free State politics after $1922 .^{63}$

A test of these children's political commitment came unexpectedly in August 1914 with the outbreak of the First World War. John Redmond's declaration in September 1914 in favour of nationalist enlistment in the British army prompted demands from opponents that M.P.s should lead by example. ${ }^{64}$ Five I.P.P. M.P.s eventually did so, with a slightly larger group (though still a minority of members) being prepared to speak on recruiting platforms. ${ }^{65}$ But some commentators went further and argued that if the M.P.s are for recruiting let ... their eligible sons [enlist]'. ${ }^{66}$ Eugene Sheehy later wrote that 'as the son of an Irish Nationalist Member of Parliament ... it was incumbent on me to answer the call' ${ }^{67}$ In fact, while he publicly supported the war, Eugene did not explicitly endorse enlistment before he received his commission in April 1915. ${ }^{68}$ By contrast, Denis Gwynn (son of the Galway City M.P. Stephen Gwynn) was 'resolutely opposed to the Irish Party's moral right to encourage young men from Ireland to go to the Front in the absence of Home Rule'. ${ }^{69}$ His decision, therefore, to follow his father in joining up in early 1916 probably reflected less a commitment to his father's politics than his admiration for the sacrifices of Irish men at the front. ${ }^{70}$

Along with Sheehy and Gwynn, a further nine sons of M.P.s served in the British army and Royal Navy during the First World War, while the son of Limerick City M.P. Michael Joyce served in the U.S. army during the conflict. These twelve men represent 22 per cent of the fifty-five sons eligible to volunteer between 1914 and 1918 (i.e. those aged between 18 and 38 at some point between 1914 and 1918). Estimates that between 'a quarter and a third of the available young men in Ireland' as a whole enlisted suggest that the party's sons were underrepresented by comparison, though the general reluctance of recruits from similar middling and 'commercial' backgrounds to enlist should be noted (nine of the twelve sons came from 'upper middle class' backgrounds). ${ }^{71}$ Four of those who served died as a result of their war service. William O'Malley was deaf in one ear and his father (M.P. for Connemara)

62 Ibid., 4 May 1908.

${ }^{63}$ On this, see Basil Chubb, The government and politics of Ireland (London, 1992), p. 88.

64 Sinn Féin, 31 Oct. 1914.

65 McConnel, The Irish Parliamentary Party, pp 297-313.

66 The Leader, 26 Sept. 1914.

67 Eugene Sheehy, May it please the court (Dublin, 1951), p. 86.

68 Freeman's Journal, 2 Feb. 1915; Irish Times, 18 Sept. 1915.

${ }^{69}$ Colin W. Reid, 'Between the Redmondite and revolutionary generations: Denis Gwynn in old and new Ireland' in Pašeta (ed.), Uncertain futures, p. 139.

70 Ibid., p. 140.

71 Keith Jeffery, 1916: a global history (London, 2015), p. 111; Niamh Puirséil, 'War, work, and labour' in John Horne (ed.), Our war: Ireland and the Great War (Dublin, 2008), p. 186; Timothy Bowman, Irish regiments in the Great War: discipline and morale (Manchester, 2003), p. 76. 
privately lobbied the War Office to prevent him from being sent to the front, but O'Malley junior evaded his father's efforts to protect him. ${ }^{72}$ Others, who survived, nonetheless experienced considerable hardship. John Redmond's son William (M.P. for East Tyrone) wrote to him from a 'dug-out' in July 1916. Describing himself as in 'mud [up] to the waist and a week's growth of beard!', William wrote to his father that 'my nerves have not given way yet, [but] the strain of the last couple of weeks has been appalling. I am still in the best of health and spirits ... It is a terrific strain, and the longer you are out here the more you feel the awfulness and gravity of the whole business. ${ }^{, 73}$

In enlisting, parliamentary nationalists envisaged that they would be fighting Germany (and, indirectly, advancing the cause of an unpartitioned Ireland), but the events of Easter 1916 meant that several M.P.s' sons ended up fighting their fellow Irishmen instead. In early 1916, Lieutenant Eugene Sheehy was training in Templemore, County Tipperary, with the $4^{\text {th }}$ Battalion Royal Dublin Fusiliers in advance of being sent to the Western Front. The outbreak of the rising, however, led to his deployment to Dublin. Decades later, Sheehy recalled his feelings at the time, 'The Rising in Easter week was a source of heartbreak to me and to the many tens of thousands of Irish Nationalists who joined the British Army. We had done so at the request of our leaders - who were the elected representatives of the people - and the vast majority of the Nation applauded our action. ${ }^{77}$ Captain John Lymbrick Esmonde, who had only succeeded his father as M.P. for North Tipperary the previous year, also served in Dublin, with the $10^{\text {th }}$ Battalion of the Royal Dublin Fusiliers, during the Rebellion. ${ }^{75}$

Other M.P.s' children were also caught up in the Rising to varying degrees. The most closely implicated was, of course, Hanna Sheehy Skeffington, who, while not 'out', was one of five people originally selected to be a 'Civil Administrator of the Government of the Republic'. She was actively involved in ferrying supplies to, and transporting messages between, the rebels. ${ }^{76} \mathrm{Her}$ husband, Francis, was also among those summarily executed during the Rising. More prosaically, the Rising disrupted the working lives of several M.P.s' children. Following the damage sustained by the premises of the Freeman's Journal newspaper during the fighting, one of its employees, J. P. Nannetti (son of the former Dublin M.P. for College Green, Dublin, of the same name) was involved in efforts to get its presses running again. ${ }^{77} \mathrm{~J}$. J. Clancy's son, Aubrey, later submitted a claim for compensation on behalf of the Dublin Rates Office for the loss of commission due to the non-payment of rates during the rebellion. ${ }^{78}$

72 William O'Malley, Glancing back: 70 years' experiences and reminiscences of press man, sportsman and member of parliament (London, 1933), p. 164.

${ }^{73}$ W. A. Redmond to John Redmond, 14 July 1916, cited in Meleady, Redmond, p. 391.

74 Sheehy, May it please the court, p. 91.

75 Neil Richardson, According to their lights: stories of Irishmen in the British army, 1916 (Dublin, 2015), p. 79.

${ }_{76}$ Charles Townshend, Easter 1916: the Irish rebellion (London, 2005), p. 161; Ward, Hanna Sheehy Skeffington, p. 155.

77 Freeman's Journal, 12 Nov. 1917.

78 Aubrey E. Clancy and Andrew J. Kettle, 'Claim for loss of commission on rates due to rebellion in Dublin' (N.A.I., Property Losses (Ireland) Committee, 1916, 
The Rebellion provoked a range of responses from the children of the I.P.P. During the Rising itself, Captain W. A. Redmond was in Ireland and reportedly 'felt a thrill of national pride at the sight of the Irish flag flying over that Government building', while the young James Dillon later wrote poetry about the courage and gallantry of the Easter rebels. ${ }^{79}$ In the failed Rebellion's aftermath, the sons of the late P. A. Meehan M.P., Father Edward Meehan and P. J. Meehan, M.P. (Leix constituency of Queen's County), lobbied the government for clemency on behalf of Eamon de Valera, who had taught at the Meehans' alma mater, Castleknock College. ${ }^{80}$ Another Meehan son, Joseph (then serving with the Irish Guards), privately wrote to his brother William 'condemning the execution' of the rebel leaders. ${ }^{81}$

The gradual shift of public opinion in favour of Sinn Féin and away from the I.P.P. after 1916 was disconcerting for the children of Ireland's home rule establishment-in-waiting. For those like Eugene Sheehy who had joined up, the years following the rising led them to question their earlier decisions. Writing over thirty years later, he recalled how,

As the tide of Irish public opinion gradually changed and hostility to England grew we did not quite know where we stood, or where our duty lay. The threat of conscription in 1918, and the ultimate betrayal of Redmond by the British Parliament, made those of us who survived feel that the thousands of Irishmen who died in Flanders, France and Gallipoli had made their sacrifice in vain. ${ }^{82}$

As Sinn Féin gained strength, some I.P.P. children publicly associated themselves with the politics of their fathers. With funerals in Ireland becoming even more politicised in the wake of the rising, the fact that all three sons of J. J. Clancy, M.P., and both of the sons of the late J. P. Nannetti, M.P., attended the funeral of John Redmond's close political ally, Pat O'Brien, M.P. (Kilkenny City), in 1917 may be significant. ${ }^{83}$ Several M.P.s' children later attended or sent their condolences to John Redmond's funeral in March 1918, which was one of the last great public demonstrations of Redmondism before the end came ten months later. ${ }^{84}$ By contrast, William Meehan's public statements as a town commissioner for Maryborough (now Portlaoise) gradually shifted between August 1917 and September 1918, from criticising Sinn Féin, to condemning the actions of crown forces in Ireland. ${ }^{85}$

Two decades after independence, Frank Aiken attacked James Dillon's lack of a revolutionary record with the words, "he was quite a young man when this country required soldiers ... where was he then?' ${ }^{86}$ In fact, this charge could be

PLIC/1/6371) (accessed online: http://centenaries.nationalarchives.ie/reels/plic/ PLIC_1_6371.pdf) (26 Nov. 2017).

79 Irish Independent, 19 Apr. 1932; Manning, James Dillon, p. 25.

80 'The Meehan brothers \& "Dev" at Knock' (https://www.knockunion.ie/news/ the-meehan-brothers-dev-at-knock-10320) (26 Nov. 2017).

81 Leinster Express, 16 Dec. 1916, 30 July 1977.

${ }^{82}$ Sheehy, May it please the court, p. 91.

83 Freeman's Journal, 16 July 1917.

84 Irish Examiner, 11 Mar. 1918; Freeman's Journal, 11, 12, 16 Mar. 1918.

${ }_{85}$ Leinster Express, 11 Aug. 1917, 14 Sept. 1918.

86 Manning, James Dillon, p. 108. 
levelled at almost all of the children of M.P.s who lived through the years 1919 to 1921. Honor Boland, daughter of J. P. Boland M.P., later married Fred Crowley, who had been in the I.R.A. during the War of Independence, while Gertrude English (daughter of John Fitzgibbon M.P.) was the sister-in-law of Ada English, who served with Cumann na mBan in Galway in 1916. But these were indirect links to the republican movement. In fact, Niall Harrington (son of the veteran Dublin Harbour M.P. Tim Harrington) was the only M.P.s' son known to have joined the I.R.A. in these years. Harrington's radicalisation predated the I.P.P.'s political annihilation in 1918. After Harrington senior died in 1910 (thereby removing a potentially restraining influence), Niall Harrington had completed his education before being apprenticed to a chemist in County Roscommon. Although Harrington became sympathetic to advanced nationalism after he heard Patrick Pearse speak in early 1916, he saw his decision to join the Irish Volunteers in early 1919 as consistent with his father's Land War activism. As a Volunteer and later I.R.B. member in Roscommon, Harrington was involved in arms raids, attacks on empty R.I.C. barracks, and the enforcement of the Belfast trade boycott before the threat of arrest forced him to flee to Dublin. He was serving with the Dublin I.R.A. when the Truce came into effect. ${ }^{87}$

Osmond Esmonde was another child whose politics took a different path to that of his father, Sir Thomas Esmonde, M.P. (North Wexford). Sir Thomas had briefly flirted with pre-war Sinn Féin, but he ultimately 'went down with the ship of constitutional nationalism' in $1918 .^{88}$ Osmond was a university student during the war but he was 'politicised by the ... rising' ${ }^{89}$ His name was considered by Sinn Féin's South Wexford candidate selection convention in advance of the 1918 general election and while he was not chosen, Esmonde supported the successful candidate against the incumbent, his own father. ${ }^{90}$ (Interestingly, James Dillon, son of John Dillon, M.P. (East Mayo), campaigned at the election in favour of Sir Thomas. ${ }^{91}$ Rather than joining the I.R.A., Osmond worked as a republican diplomat in England, North America, and Australasia. On a diplomatic world tour in 1921, he was not allowed to disembark in Australia or New Zealand, he was deported from Fiji, and, in Canada, he was detained and put on trial. ${ }^{92}$

Mary (Moya) O'Connor was also caught up in the War of Independence. She was the only surviving daughter of the ex-Fenian, turned M.P. (West

87 Niall C. Harrington, Kerry landing: an episode of the Irish Civil War (Dublin, 1992), pp 47-61.

88 McConnel, The Irish Parliamentary Party, pp 125-9. See also Richard Keogh and James McConnel, 'The Esmonde family of Co. Wexford and Catholic loyalty' in Oliver P. Rafferty (ed.), Irish Catholic identities (Manchester, 2013), pp 272-91. The phrase is Michael Wheatley's. See his Nationalism and the Irish Party: provincial Ireland, 1910 1916 (Oxford, 2005), p. 136.

89 Pauric J. Dempsey and Shaun Boylan, 'Esmonde, Sir Osmond Thomas Grattan', in Dictionary of Irish Biography (D.I.B.).

${ }^{90}$ Freeman's Journal, 24 Sept. 1918.

91 Maurice Manning, 'Dillon, James Matthew', in D.I. B.; idem, James Dillon, p. 23.

92 Dempsey \& Boylan, 'Esmonde, Sir Osmond Thomas Grattan'; Freeman's Journal, 12, 15 Jan., 1 July, 9 Sept. 1921; 'Report on the mission to New Zealand and Australia by Osmond Grattan Esmonde' (N.A.I., Department of Foreign Affairs, E.S., box 32, file 220; accessed online via Documents on Irish Foreign Policy: http://www.difp.ie/ docs/1921/Australia-New-Zealand/105.htm) (3 Jan. 2018). 
Wicklow), James O'Connor, her mother and four siblings having all died as a result of poisoned shellfish during the 'Seapoint tragedy' of 1890. Following her father's remarriage, she moved to England and later became active in the Edwardian-era Women's Liberal Association. ${ }^{93}$ In 1909, she married Crompton Llewelyn Davies, a one-time member of the Cambridge Apostles (an intellectual society at Cambridge University that included Lytton Strachey and J. M. Keynes), a prominent Liberal land reform advocate, and (from 1912) official solicitor to the post office. The 1916 Easter Rising had a 'profound effect' on Moya, making her realise 'for the first time [that] ... she was really an Irish woman'. 94 She and her husband both worked for the reprieve of Sir Roger Casement behind the scenes, but her revolution really began after 1918. Accounts differ as to when she first met Michael Collins but they definitely encountered one another in 1919 when she and her husband helped Collins in his efforts to contact President Woodrow Wilson. ${ }^{95}$

Historians have viewed Moya's career during the War of Independence very differently. Meda Ryan has argued that in these years she was 'an essential part of Collins' intelligence network' and that her links to the British establishment made her one of Collins's 'strong team of intelligence women' ${ }^{96}$ By contrast, Peter Hart presented Moya as a 'lonely and vulnerable figure' who became 'something of a stalker' of Collins. ${ }^{97}$ Others have speculated that she may have been a British spy or even that she bore Collins a child, whose existence was used to blackmail him into signing the Treaty. ${ }^{98}$ What is beyond doubt is that this 'tall, thin, agile, extremely elegant' women clearly relished revolutionary politics. When, in March 1921, she was arrested and incarcerated in Dublin's Mountjoy prison, she wrote that 'revolutions are splendid and I now understand the Russian and French ones in a way which I never could have done before'. 99

Joseph Meehan had privately criticised the executions of the rebel leaders in 1916 and, following his demobilisation from the army, he became an increasingly vocal critic of Dublin Castle. As a Maryborough town commissioner, he condemned the 'murder' of Tomás Mac Curtain, lord mayor of Cork, in March 1920, declaring that 'I am ashamed that I am an ex-officer of the Army who allowed the Lord Mayor to be murdered by Lloyd George's gang of blackguards. ${ }^{, 100}$ And following the death on hunger strike of Terence MacSwiney, in October 1920, Meehan paid tribute to MacSwiney's 'heroic fortitude'. Meehan was arrested alongside a number of other local men and taken to the Curragh the following month. ${ }^{101}$ His brother, the former M.P., P. J. Meehan, apparently secured his release but Joseph Meehan refused to accept unless his fellow prisoners were freed and since this was not granted he

\footnotetext{
93 Mrs George Gavan Duffy statement (N.A.I., B.M.H., W.S. 712).

94 Ibid.

95 Meda Ryan, Michael Collins and the women who spied for Ireland (Dublin, 2006), p. 51; Tim Pat Coogan, Michael Collins: a biography (London, 1990), p. 108.

96 Ryan, Michael Collins and the women who spied for Ireland, pp 12, 64.

97 Peter Hart, Mick: the real Michael Collins (London, 2005), p. 352.

98 Coogan, Michael Collins, p. 287-7; Southern Star, 12 Oct. 1996.

99 Coogan, Michael Collins, p. 109; W. C. Lubenow, The Cambridge Apostles, 1820-1914: liberalism, imagination, and friendship (Cambridge, 1998), p. 195.

100 Leinster Express, 30 July 1977.

101 Leinster Express, 27 Nov. 1920.
} 
remained interned until after the Truce. ${ }^{102}$ Another former soldier whose father had been an I.P.P. M.P., Louis Abraham, was president of the Cambridge Union (the university debating society) in 1920 and in that role condemned 'the policy of the Government in Ireland during the Black and Tan war'. ${ }^{103}$

Unlike Harrington, Esmonde, O'Connor, and Meehan, most ex-M.P.s' children did not publicly side or express sympathy with Sinn Féin in the years 1919-21. Some, like James Dillon, clung to the politics of the old order (at U.C.D. after 1919 he was known as one of 'the last frontiersmen' of the I.P.P.), while others sought to find non-republican alternatives to Sinn Féin (Mary Kettle supported the Irish Dominion League). ${ }^{104}$ A number, though not combatants, were nonetheless caught up in the turbulence of these years. Johanna Redmond and her husband had to persuade the local I.R.A. not to burn down the Redmond family home, Aughavanagh, in the summer of $1920{ }^{105}$ The Castlerea home of Gertrude English (née Fitzgibbon) was raided in 1920, perhaps owing to the republican activities of her sister-in-law. ${ }^{106}$ But most I.P.P. children seem to have 'taken the revolution in their stride', having become, as John Dillon wrote of his own children in these years, 'absolutely hardened'; they 'go and come by day and night as if they were living in a civilised country', he wrote. ${ }^{107}$ For those like Herbert J. Clancy, appointed secretary to Dublin County Council in 1919 (with some help from the veteran ex-M.P. William Field), their lives do not seem to have been significantly affected by contemporary events. Likewise, for Francis Meehan, who took over the family shop in 1919, Anne O'Dowd, who continued her medical studies at U.C.D. throughout these years, Aloysius Farrell, who took over the Longford Printing and Publishing Company following his father's death in 1921, and James Dillon, who undertook an apprenticeship at Selfridges in London, life continued. ${ }^{108}$

Of course, the establishment of the Free State in 1922 posed certain challenges for the children of the old regime. Their fathers' ambition of a restored parliament had finally been achieved, but only for twenty-six counties, and by the sworn enemies of the party they had served, who now became independent Ireland's new political establishment. While most ex-M.P.s withdrew from Irish public life after 1918, a number of their children sought to come to terms with the new regime from an early stage. Shaun Dillon, for example, was willing to give the Free State the benefit of the doubt, telling his more sceptical brother James 'by the time you resume residence in Ireland our Parliament will be in full swing. ${ }^{, 09}$ P. J. Meehan became the Free

\footnotetext{
102 Leinster Express, 30 July 1977.

103 Irish Times, 13 Feb. 1965.

104 Manning, James Dillon, p. 27; Senia Pašeta, 'Women and civil society: feminist responses to the Irish constitution of 1937' in Jose Harris (ed.), Civil society in British history: ideas, identities, institutions (Oxford, 2005), p. 224.

${ }^{105}$ Katherine Barry-Moloney statement (N.A.I., B.M.H., W.S. 731).

106 Freeman's Journal, 27 July 1920.

107 John Dillon to T. P. O'Connor, 8 Feb. 1923, cited in F. S. L. Lyons, John Dillon: a biography (London, 1968), p. 472.

108 Irish Independent, 19 Sept. 1919; Leinster Express, 3 Oct. 1981; Laura O'Kelly, Irish women in medicine, c.1880s-1920s: origins, education, and careers (Manchester, 2012), p. 227; Leinster Express, 27 Aug. 1949; Manning, James Dillon, p. 31.

109 Shaun Dillon to James Dillon, 24 Nov. 1921, cited in Manning, James Dillon, p. 34.
} 
State solicitor for Laois (having occupied the equivalent office under Dublin Castle until 1922) and served the new state until his death in $1929 .{ }^{110}$ Eugene Sheehy's earlier uncertainty was replaced by a willingness to support, if never 'whole heartedly', the new state, as he accepted the role of judge advocate general to the new National Army in June 1922, and from June 1923 to January 1925 he acted as a judicial commissioner for the Dáil courts. ${ }^{111}$ Thereafter he enjoyed a distinguished judicial career in the service of the Free State and its successor, becoming in the process a 'minor pillar' of the new order. ${ }^{112}$ According to his nephew, 'The new government needed such allies, but its relations were necessarily a little constrained ... Allies like Eugene were needed, in the struggle against the extreme Republicans, but they were compromising allies.' ${ }^{113}$ Though Sheehy continued to be associated with the remnants of the old Irish Party after 1922, his re-alignment with the Free State heightened existing tensions with his sister Hanna (who remained a bitter critic of the Treaty), though 'they never broke with one another'. ${ }^{114}$

For those who had supported Sinn Féin before 1922, the early days of the new state were 'exciting and tumultuous' ones. ${ }^{115}$ Niall Harrington recalled that in late 1921 the 'air was full of wishful speculation' about the future. Consequently, what he termed the 'unhappy conflict of brother against brother' that followed the Treaty debates produced 'disillusionment' and 'shameful deeds' on both sides. Harrington served in Dublin with Free State forces during the early stages of the Civil War and then with the Dublin Guards in Kerry. Promoted to second lieutenant for his bravery in action, he became a captain in 1923 and for the next fifty years served the new state as a professional soldier.

Like Harrington, Moya O'Connor's optimism of late 1921 gave way to disenchantment (in a manner not untypical of the revolutionary generation considered in Roy Foster's Vivid faces and Frances Flanagan's Remembering the revolution). ${ }^{116}$ As O'Connor wrote to one correspondent, 'M[ichael Collins] saw in it [the Treaty] enormous potentialities if we got a few months breathing space. But all that is altered now. The glory is all gone there is nothing but sadness and pain and disillusion left behind., ${ }^{117}$ Like Harrington and O'Connor, Osmond Esmonde sided with the treatyites in 1922. After 1922 he held a series of Free State diplomatic posts in England, Spain, and Italy, and he was a member of its delegation to the League of Nations in 1923. 118

110 Meath Chronicle, 20 Jan. 1923.

111 O'Brien, States of Ireland, p. 104.

112 Daire Hogan, 'Sheehy, Eugene', in D.I.B; Irish Times, 18 Feb. 1928; O'Brien, States of Ireland, p. 105.

113 O'Brien, States of Ireland, p. 105.

114 Irish Examiner, 1 May 1925; Evening Herald, 1 Jan. 1927; O’Brien, Memoir, p. 62; O'Brien, States of Ireland, p. 106.

${ }^{115}$ Harrington, Kerry landing, pp 47-61.

116 Foster, Vivid faces; Frances Flanagan, Remembering the revolution: dissent, culture, and nationalism in the Irish Free State (Oxford, 2015).

117 Margaret O'Callaghan, 'Introduction' in Angela Bourke et al., (eds), The Field Day anthology of Irish writing, v: Irish women's writing and traditions (Cork, 2002), p. 123.

118 Dempsey \& Boylan, 'Esmonde, Sir Osmond Thomas Grattan'; Irish Examiner, 8 Jan. 1923; Ulster Herald, 13 Jan. 1923. 
The children of other ex-M.P.s were also caught up in Ireland's Civil War. Two of the Dillon sons were sent to Roscommon during the conflict to try to protect the family's property there. ${ }^{119}$ James Dillon lost university friends who fought with the Irregulars. ${ }^{120}$ Brian Dillon was almost arrested by troops in late 1922, while his sister Anne was forced to remain indoors on one occasion owing to a 'furious' firefight that went on for two hours outside. ${ }^{121}$ Anti-Treaty forces briefly kidnapped P. J. Meehan in April 1923. ${ }^{122}$ When a letter written by the former Kerry M.P. Tom O'Donnell's young son, Tom, was intercepted by the authorities, its expression of 'total support' for the anti-treatyites apparently led to a visit by Free State soldiers and the mistaken arrest of another son, Michael. Appeals to the governor general, the former nationalist M.P. Tim Healy, secured the boy's release. ${ }^{123}$ Johanna Redmond's husband Max Green was killed trying to stop a bank robbery in early 1922, in an event which, if not directly connected to the Civil War, was influenced by the breakdown in public order associated with the period.

\section{III}

The promise of an end to the political instability and violence of the revolutionary years led some old parliamentary nationalists, like John Dillon, initially to advocate 'support[ing] the new government and do[ing] all in their [power] to give it a fair chance to restore order'. ${ }^{124}$ But whereas for Dillon and most of his former colleagues (whose average age was now well over 60) this meant watching from the sidelines; their sons and daughters had to find ways of coming to terms with the new regime. If their earlier dreams of debating in College Green were now gone, this disappointment was tempered in many cases by their ambition, ability, and pragmatism. Rather than being unable to 'adapt to Ireland's changed political circumstances', the children of a number of former M.P.s mustered their residual political capital to engage with, but also shape, the politics of the new state. ${ }^{125}$ After all, the great majority of them shared the religious preferences of the new state's rulers (with 11 of the 247 children becoming Catholic priests, monks, or nuns), while most were able to accommodate themselves to the privileged status given to the Irish language and culture after 1922.

John Regan has advanced the thesis that a two-phase 'counter-revolution' was carried out in Ireland during the 1920s by the pro-Treaty party, Cumann na nGaedheal, under the direction of Kevin O'Higgins. O'Higgins was the Clongowes and U.C.D. educated grandson of an I.P.P. M.P. (who had retired in 1900), while his close ally Patrick McGilligan had a similar background and

\footnotetext{
119 Manning, James Dillon, p. 33.

120 Ibid., p. 28

121 Brian Dillon to Theo Dillon, 17 Nov. 1922; John Dillon to Myles Dillon, 25 Nov. 1922, cited in Joachim Fischer and John Dillon (eds), The correspondence of Myles Dillon, 1922-1925 (Dublin 1999), pp 47, 53.

122 Southern Star, 14 Apr. 1923.

123 Gaughan, A political odyssey, pp 141-2.

124 John Dillon to T. P. O'Connor, 27 Jan. 1921, cited in Lyons, John Dillon, p. 469.

125 Senia Pašeta, 'Ireland's last home rule generation: the decline of constitutional nationalism in Ireland, 1916-30' in Michael Cronin and John M. Regan (eds), Ireland: the politics of independence, 1922-49 (Basingstoke, 2000), p. 26.
} 
was the son of a former anti-Parnellite M.P. The second phase of this counterrevolution involved the 'O'Higginisation of Cumann na nGaedheal ... [so] that ... the post-revolutionary elite, in terms of its composition and its dominant political culture, appeared to share much in common with the prerevolutionary nationalist elite'. ${ }^{126}$ If so, this did not facilitate the smooth or immediate assimilation of former home rulers, such as the children of I.P.P. M.P.s. Instead, Regan notes that during the 1920s, the 'treatyites were at all times vulnerable on their right flank, relying on the latent support of a disaffected, and in the wake of the collapse of the Irish parliamentary party after 1918, a disorganised, non-Sinn Féin nationalist constituency'. ${ }^{127}$ Evidence of this can be seen in the political choices made by several ex-M.P.s' children during the early 1920s. Henry M. Fitzgibbon (son of the former Roscommon M.P. John Fitzgibbon) stood at the 1923 general election as an independent candidate for Roscommon, on a platform that demanded 'impartial' trials for republican prisoners, while supporting the Treaty as 'the shortest and best course to absolute freedom'. ${ }^{128}$ Frank Phillips (son of the former South Longford M.P.) was a 'large farmer' and a member of the County Longford Farmer's Association. ${ }^{129}$ In 1923 he was selected as a Dáil candidate alongside another former I.P.P. supporter Patrick McKenna - for the Farmers' Party (the political vehicle of the Irish Farmers' Union) at the general election, and he also stood as a candidate at local elections in 1925 . $^{130}$ Despite internal divisions, the Farmer's Party was broadly supportive of the governing Cumann na nGaedheal party. ${ }^{131}$ James Nugent (one of the sons of the former College Green Dublin M.P. J. D. Nugent) was friendly with McKenna when the latter was a Farmer's Party T.D. in the mid-1920s. ${ }^{132}$

Falling support for the Farmers' Party led it to consider merging with the governing party in the later 1920s but also with the new National League Party. The latter was founded in late 1926 by the former M.P.s W. A. Redmond and Tom O'Donnell in an effort to bring the remnants of the I.P.P. back into public life, provide a constitutional pro-Treaty opposition to the government, and 'break the Civil War mould' into which Free State politics was threatening to settle. ${ }^{133}$ Redmond had been elected as an independent T.D. as early as 1923 , despite efforts by Cumann na nGaedheal to recruit him. ${ }^{134}$ The emergence of the National League Party highlighted the threat to the government of independent pro-Treaty parties on its right flank. Kevin O'Higgins saw the National League and Farmers' Party as 'wretched little parties vigorously sawing the bough they are sitting on'. ${ }^{135}$ The decision of Fianna Fáil to enter the Dáil in August 1927 changed the dynamics of Free

\footnotetext{
126 Regan, The Irish counter-revolution, pp 244-9, 378.

127 Ibid., pp 264-5.

128 Freeman's Journal, 17 Aug. 1923.

129 Longford Leader, 23 Oct. 1920, 12 May 1923.

130 Freeman's Journal, 10 Aug. 1923; Longford Leader, 6 June 1925.

131 Regan, The Irish counter-revolution, p. 241.

132 Evening Herald, 25 June 1926.

133 Manning, James Dillon, p. 43; Marie Coleman, 'Redmond, William Archer Redmond', in D.I.B.

${ }_{134}$ Regan, The Irish counter-revolution, p. 142.

135 Kevin O'Higgins to Frank McDermott, 18 May 1927, cited in Manning, James Dillon, p. 60.
} 
State politics and created an opportunity for the National League to help oust Cumann na nGaedheal from government. The same month a vote of no confidence in the government was supported by a coalition of LabourNational League T.D.s, with Fianna Fáil backing. A coalition ministry was envisaged (and portfolios earmarked accordingly), but the unwillingness of some National League T.D.s to depose the government contributed to the motion's defeat by the narrowest of margins. Had it succeeded, Redmondites would finally have achieved power in a Dublin parliament. ${ }^{136}$

The unsuccessful Dáil vote highlighted the National League's internal divisions and 'severely dented' its political credibility; at the September 1927 general election it slumped from eight to two seats. ${ }^{137}$ It struggled to be more than a 'disparate coalition ... of ... licensed trade[rs], Hibernians, ex-servicemen and political opportunists who hoped to capitalise on [the] Government['s] unpopularity'. ${ }^{38}$ Along with W. A. Redmond, two of Tom O'Donnell's daughters supported the League, as did Desmond Duffy (son of the former South Galway M.P. William Duffy), and J. P. Nannetti. ${ }^{139}$ But other I.P.P. children only flirted with it. John L. Esmonde showed some initial interest but ultimately opted to throw his weight behind Cumann na nGaedheal in 1927. ${ }^{140}$ James Dillon campaigned for the League at the June 1927 general election, but he refused an offer to stand for parliament. He regarded the National League Party's 1927 manifesto as 'insipid' and he held a low opinion of the political abilities of W. A. Redmond. ${ }^{141}$ His opinion was not improved by the abortive Labour-National League gambit of August $1927 .^{142}$

The emergence of Fianna Fáil and the demise of the National League meant that by the early 1930s Cumann na Gaedheal was increasingly becoming the 'natural party' for supporters of the old I.P.P. ${ }^{143}$ Owen Esmonde (son of Dr John Esmonde M.P. for North Tipperary) was associated with Cumann na Gaedheal from at least 1930, while the husband of Mary Duggan (daughter of John Fitzgibbon) was a former staunch Redmondite now turned 'a warm supporter of Cumann na nGaedheal'. ${ }^{144}$ Following the winding up of the now moribund National League Party in 1931, W. A. Redmond joined Cumann na nGaedheal and shortly before his early death he was successfully elected on its ticket at the 1932 general election. Despite Cumann na nGaedheal's overtures to James Dillon, he continued to remain aloof from both of the post-Civil War parties and instead campaigned for the National Farmers' and Ratepayers' League candidate in Roscommon at the 1932 general election, while standing himself as an independent candidate for Donegal (supported by the former M. P. for Dublin College Green and Ancient Order of Hibernians (A.O.H.)

136 Ciara Meehan, The Cosgrave party: a history of Cumann na nGaedheal, 1923-33 (Dublin, 2010), pp 100-05.

137 Manning, James Dillon, p. 44.

138 Regan, The Irish counter-revolution, p. 265.

139 Gaughan, A political odyssey, p. 167; Connacht Tribune, 28 May 1927; Irish Independent, 14 Dec. 1926.

${ }_{140}$ Gaughan, A political odyssey, p. 161, 168; Manning, James Dillon, p. 43.

141 Gaughan, A political odyssey, pp 151-3; Irish Times, 25 May 1927.

142 Manning, James Dillon, pp 32, 47.

143 Ibid., p. 47.

144 Nenagh Guardian, 5 Apr. 1930; Irish Independent, 3 June 1933. 
general secretary, J. D. Nugent, and his son Peter). ${ }^{145}$ But Dillon's increasing hostility to the Fianna Fáil government eventually persuaded him to ally with other 'neo-Redmondite[s]' (such as John L. Esmonde) in forming the National Centre Party in 1933, and he was also instrumental in the subsequent merger of parties that produced Fine Gael in 1933. ${ }^{146}$ Alongside Dillon, Peter Nugent was one of the six inaugural vice-presidents of the new party. In addition, his brother James supported Fine Gael, as did Frank Phillips (formerly of the Farmers' Party), and Desmond Duffy. ${ }^{147}$

Fine Gael was formed against a backdrop of anxiety regarding the activity of the I.R.A., the effects of the economic war, and the determination of the Fianna Fáil government to alter the constitution. This context also contributed to the creation of the Army Comrades Association (the so-called 'Blueshirts'). While James Dillon and Desmond Duffy associated themselves with the Blueshirts, among the children of the I.P.P. Osmonde Esmonde was by far the most closely connected with this organisation. ${ }^{148}$ Having been a Cumann na nGaedheal T.D. as early as 1923, Esmonde had defected to the National Group in 1924, only returning to the governing party in 1927 . He was re-elected to the Dáil that year, and later joined Fine Gael on its foundation. ${ }^{149}$ In the 1930s he was a member of the national council of the Army Comrades Association, a co-founder of the later League of Youth (as the Blueshirts became), and an associate of Eoin O'Duffy. His 1935 description of Mussolini as the 'Abraham Lincoln of Africa' lent credence to accusations that the Blueshirts were crypto-fascists. ${ }^{150}$

More than any other Irish political party founded after 1922, the formation of Fine Gael in 1933 provided the children of the I.P.P. with a way back into mainstream Irish politics. That they gravitated so overwhelmingly towards Fine Gael is revealing not only of their post-1922 political alignments but also of the formative political influences so many had experienced. After all, with the exception of Honor Crowley (who succeeded her husband as Fianna Fáil T.D. for Kerry South in 1945), six of the seven other I.P.P. children who were in the Dáil after 1933 were members of Fine Gael. Likewise, with the exception of Hanna Sheehy Skeffington's role in the founding of Fianna Fáil, at least six I.P.P. children were active grassroots supporters of Fine Gael (especially in the 1930s), with John Witham Esmonde standing as a local government candidate for Fine Gael as late as $1974 .{ }^{151}$ Sir John L. Esmonde, the former nationalist M.P., one-time Royal Dublin Fusilier, and (from 1937) Fine Gael T.D., was even considered as a possible taoiseach during the formation of the 1948 inter-party government, on the basis that he had not taken sides during the

145 Manning, James Dillon, pp 27-51.

146 Michael Gallagher, Political parties in the Republic of Ireland (Manchester, 1985), p. 102; Lawrence William White, 'Esmonde, Sir John Lymbrick', in D. I.B.

147 Longford Leader, 14 Oct. 1933; Connacht Tribune, 7 Nov. 1933.

148 Connacht Tribune, 7 Nov. 1933; Manning, James Dillon, p. 73.

149 Pauric J. Dempsey and Shaun Boylan, 'Esmonde, Sir Osmond Thomas Grattan', in D.I.B.

150 Ibid.

151 Nenagh Guardian, 5 Apr. 1930; Manning, James Dillon, p. 386; Longford Leader, 14 Oct. 1933; Connacht Tribune, 7 Nov. 1933; Irish Press, 16 Apr. 1937; Irish Examiner, 24 May 1974. 
Civil War. ${ }^{152}$ The possession of a baronetcy, however, apparently counted against Esmonde (because of its perceived connections to the British crown). ${ }^{153}$ Nonetheless, he was also considered as a possible minister for external affairs in 1949 and for attorney general in $1950 .{ }^{154} \mathrm{He}$ resigned from Fine Gael that year, complaining (among other things) that the party was ignoring the old National League Party element that had helped form Fine Gael in 1933. ${ }^{155}$ When Esmonde died in 1958, the president, Sean T. O'Kelly, was represented at his funeral, while Sean Lemass, John A. Costello, Liam Cosgrave, and Sean MacEoin all attended. ${ }^{156}$

James Dillon himself might have become taoiseach in 1948 but for his resignation from the party in 1942 over the question of Irish neutrality during the Second World War (his lifelong friend Peter Nugent also resigned from Fine Gael on the same issue). ${ }^{157}$ An advocate of Ireland's continued membership of the British Commonwealth and a critic of the Nazis, Dillon found himself out of sympathy with Irish policy during the war. In this, he was not alone among the children of nationalist M.P.s. John Redmond Hayden (son of the former South Roscommon M.P. John Hayden) served as an officer in the Royal Artillery during the war in Madagascar and Burma. ${ }^{158}$ Hayden's wife, Cilla, also 'spent an active period of her life attached to the army' during the war. ${ }^{159}$ Peter Nugent (son of the South Westmeath M.P. Sir Walter Nugent) enlisted in the Irish Guards and served with the Indian army at the jungle warfare training school in Bombay during the war. ${ }^{160}$ His sister Gloria married an officer in the Irish Guards in 1946. ${ }^{161}$ The son of Hugh Law (M.P. for West Donegal), Francis, had fought in the First World War with the Irish Guards and remained in the British Army until 1931. He led a territorial battalion of the Border Regiment to France in 1940 and was evacuated at Dunkirk. ${ }^{162}$ Two of Law's sisters were married to high-ranking officers who served in the war. Four of the children of Dr John Esmonde M.P. fought in the Royal Navy during the war; among them, Eugene Esmonde was posthumously awarded the Victoria Cross in 1942 for leading the 825 Swordfish Squadron of torpedo bombers in a desperate attack on two German battle cruisers in the English Channel. ${ }^{163}$ Their cousin Patricia (the daughter of

152 D. R. O'Connor-Lysaght, The Republic of Ireland: an hypothesis in eight chapters and two intermissions (Cork, 1970), p. 142.

153 J. H. Whyte, 'To the declaration of the Republic and the Ireland Act, 1945-9' in J. R. Hill (ed.), A new history of Ireland, vii: Ireland, 1921-1984 (Oxford, 2003), p. 269.

${ }_{154}$ Patrick Lynch, 'More pages from an Irish memoir' in Richard English and Joseph Morrison Skelley (eds), Ideas matter: essays in honour of Conor Cruise O'Brien (Oxford, 2000), p. 130.

155 Irish Times, 25 Sept. 1950.

156 Irish Independent, 9 July 1958.

157 Maurice Manning, 'Dillon, James Matthew', in D.I.B.; Irish Independent, 20 Feb. 1942.

158 Westmeath Examiner, 30 Aug. 1997.

159 Ibid., 10 May 2003.

160 Daily Telegraph, 26 Dec. 2002.

161 Irish Independent, 30 Nov. 1946.

162 Francis Law, A man at arms: memoirs of two world wars (London, 1983), pp 157-70.

163 Nenagh Guardian, 21 Feb. 1942; Irish Press, 13 Apr. 1942; Chaz Bowyer, Eugene Esmonde, VC, DSO (London, 1983). 
Sir Thomas Esmonde) was married to a U.S. naval officer who by 1941 was U.S. Destroyer Division Commander in the Atlantic. ${ }^{164}$ Bridget Boland (sister of Honor) worked in the War Office writing plays for the troops. ${ }^{165}$ William, the son of Tom Lundon M.P. was an R.A.F. fighter pilot who was killed in 1942. ${ }^{166}$ Two sons of one ex-M.P. deserted from the British forces during the war and were later convicted for burglary in the late 1940s. ${ }^{167}$

While this military service may well reflect what Conor Cruise O'Brien termed the supposedly 'genetically transmitted inclination to be pro-British' of family members of ex-M.P.s, that tens of thousands of Irishmen and women fought against the Axis powers during the war means that the children of the I.P.P. were hardly unique. ${ }^{168}$ Likewise, that so many M.P.s' children chose to live and work in Britain before, and especially after, the Second World War reflected not only a degree of Anglophilia but also economic realities. Father Patrick Reddy served as a priest in Manchester until 1940. ${ }^{169}$ After the war, J. R. Hayden became a stockbroker in Liverpool. ${ }^{170}$ The son of Richard McGhee M.P. (Mid Tyrone), Henry George McGhee, was the Labour M.P. for Penistone, West Yorkshire, from 1935 until 1959, and was associated with the Friends of Ireland and the Anti-Partition League. ${ }^{171}$ Dr John O'Donnell and Dr C. Donnelly both practised as G.P.s in England. ${ }^{172}$ The Blackrock College educated son of the longest-living I.P.P. member was a chartered accountant in Birmingham. ${ }^{173}$

Many, of course, made their homes in London. As Enda Delaney has noted for an earlier period, 'For middle class [Irish] professionals seeking to improve career prospects, London was the place to go. Opportunities for advancement and preferment far exceeded those in Dublin or provincial Ireland. ${ }^{, 174}$ While some of the same advantages applied to the other English metropolitan destinations that I.P.P. children settled in, London's Irish population was not only large and socially diverse, but also a place that many of them had been familiar with since childhood. By the mid-1960s, one in five of the LondonIrish was middle class. ${ }^{175}$ In this environment, Bridget Boland became a screenwriter and playwright. Alec Guinness appeared in the film of her play The prisoner (1955), though it was banned in Ireland for being 'anti-Catholic' and pro-communist. ${ }^{176}$ She also adapted the screenplay for War and peace (1956) and wrote the screenplay for Anne of a thousand days (1969), for which she won an Oscar. Gloria Nugent (daughter of Sir Walter Nugent M.P.) married the Irish actor Jack MacGowran in 1963 in London, with Peter

164 Irish Press, 7 Dec. 1957.

165 Irish Independent, 1 June 1966.

166 Ibid., 12 June 1942.

167 Irish Press, 27 July 1948.

168 O’Brien, Memoir, p. 8; Irish Times, 13 Feb. 2016.

169 Irish Press, 31 Dec. 1940.

170 Westmeath Examiner, 30 Aug. 1997.

171 Ulster Herald, 17 Nov. 1945.

172 Irish Press, 14 Nov. 1947; Gaughan, A political odyssey, p. 139.

173 Irish Examiner, 24 Sept. 1956.

174 Enda Delaney, The Irish in post-war Britain (Oxford, 2007), p. 89.

175 Ibid., p. 92.

176 Irish Independent, 1 June 1966; Tony Shaw, British cinema and the Cold War: the state, propaganda, and consensus (New York, 2006), p. 81. 
O'Toole as best man. ${ }^{177}$ Louis Abraham C.B., C.B.E. became a senior parliamentary clerk in the House of Commons. ${ }^{178}$ Another of Sir Walter Nugent's daughters, Lady Pritchard Jones, co-founded the Westmeath Association in London, while Mary Byrne (daughter of Alfie Byrne, M.P. for Dublin Harbour) helped found the Dublin Association of London and the Martin House Association (which rehabilitated women offenders in London). ${ }^{179}$

When taken together, this evidence suggests that these children moved freely between post-war Ireland and Britain for family and professional reasons by choice. Indeed, when examining the cohort as a whole at the mid-century point, the socio-economic profile of the children of ex-M.P.s clearly places them among the Free State's upper middle class, while the prominence of a number of them means that quite a few were also members of independent Ireland's establishment. This is not to deny that some (possibly most) of the children felt that the defeat of the I.P.P. had dented their prospects; but the available evidence does not suggest arrested development. In this regard, Tom Garvin's comparison of the I.P.P. in 1910 with Dáil deputies from 1918 and 1948 provides a useful perspective when considering the upper middle class position of the children of the I.P.P. by the mid-twentieth century:

The separatists [of 1918] were far more bourgeois, in the strict sense, than their Redmondite predecessors. They ... were far less likely to be members of the higher professions. Comparison is difficult, as the revolutionary leaders came into politics at a period when their own careers had not yet become clearly defined. A comparison of the Irish Party MPs with the Dáil deputies of 1918 does not reveal an enormous gap in status, but a comparison ... with the separatist elite in middle age is quite revealing: by 1948 Dáil deputies were only half as likely to be members of the higher professions as the 1910 group had been, and were far more likely to be businessmen, farmers, or trade union officials. ${ }^{180}$

Of the I.P.P. children considered in this article, 99 men and women were definitely alive in 1948 and occupational data exist for 59 of them (i.e., 60 per cent of the 99). 83 per cent of this cohort of 59 had 'higher' (in the sense that Lyons's used it) occupational profiles by 1948. Seventeen per cent of the 59 were lawyers (both solicitors and barristers), 10 per cent were engineers, while politicians (both T.D.s and M.P.s) and Catholic religious accounted for 9 per cent each. Among those of the 59 with 'lower' middle-class occupational profiles, merchants and farmers taken together only accounted for 7 per cent in 1948. Additionally, occupational data exist for ten of the husbands of M.P.s' daughters alive in 1948, of whom five were married to doctors and nine overall were members of the higher professions. Of the 50 sons alive in 1948, 13 (or 26 per cent) had been educated at one of Ireland's elite schools (a further 4

178 The Times, 2 Feb. 1982.

179 Westmeath Examiner, 8 June 1974; Irish Independent, 28 Aug. 1951, 20 Feb. 1967.

180 Tom Garvin, Nationalist revolutionaries in Ireland, 1858-1928 (Oxford, 1987), p. 56. See also Tom Garvin, 'Declonisatation, nationalism, and electoral politics in Ireland, 1832-1945' in Otto Büsch, (ed.), Wählerbewegung in der Europäischen geschichte (Berlin, 1980), p. 279. 
had been educated at Downside in England). The equivalent figure before the war had been 13 per cent. And of the 99 sons and daughters definitely alive in 1948, 19 per cent had been university educated (in 1910 this figure had been 11 per cent).

While only one I.P.P. child actually reached ministerial rank after 1922, other I.P.P. children made a considerable contribution to the public life of the Free State and its successor, whether as activists, local government civil servants, higher-education lecturers, lawyers, soldiers, and so on. As chair of the Joint Committee of Women's Societies and Social Workers, Mary Kettle played a 'prominent role' in the feminist campaign concerning women's rights and the 1937 constitution, in relation to which she referred approvingly of 'the classic simplicity of the language of the Proclamation of the Republic'. ${ }^{181}$ James Nugent served as the first chairman of Bord Fáilte from 1950 onwards. ${ }^{182}$ Desmond Duffy was a member of the Irish Greyhound Board in the 1960s. ${ }^{183}$ Others were connected to the state via more informal networks: Eileen Esmonde, for example, was married to Dermod St John Gogarty, the second son of Senator Oliver St John Gogarty. ${ }^{184}$

Of course, had the First World War and the 1916 Easter Rising not happened, it is likely that more of these children would have been prominent in the public life of self-governing Ireland. The operation of what political scientists have termed 'legacy advantage' for the sons and daughters of political representatives seeking election was already a feature of Irish politics before 1918 and it intensified after $1922 .{ }^{185}$ Moreover, there is some anecdotal evidence to suggest that, after 1922, being the sons and daughters of their fathers did sometimes hinder the professional opportunities of I.P.P. children. Myles Dillon's failure to succeed Douglas Hyde in 1932 to the chair in Irish at U.C.D. has been attributed in part to his unpopular view that home rule would have been better for Ireland than the settlement that emerged after the Anglo-Irish war'. ${ }^{186}$

That said, with or without home rule, the great majority of the 247 children born to nationalist M.P.s elected between 1910 and 1918 would almost certainly still have led interesting, if politically unremarkable, lives. In all likelihood, they would still have ended up running greyhound tracks in Kerry, prospecting for oil around the globe, working as travel agents in Limerick, selling insurance, training racehorses, treading the boards of inter-war British and Irish music halls, and raising families. But even these more mundane trajectories have significance, since what these men and women did not do after 1922 was leave Ireland, let alone disappear. Despite the turbulence of the years after 1916, many of the children of the I.P.P. quickly found their feet under the new regime. If very few of them had James Dillon's 'unshakeable belief' that he belonged at the centre of Irish public life no matter what, many of them possessed professional and political ambitions that were undimmed by

181 Irish Examiner, 15 July 1937; Pašeta, 'Women and civil society', pp 224-5; Senia Pašeta, Irish nationalist women, 1900-1918 (Cambridge, 2013), p. 271.

182 Irish Times, 5 Oct. 1950.

183 Connacht Tribune, 28 May 1960.

184 Irish Independent, 11 July 1935.

185 Daniel M. Smith and Shane Martin, 'Political dynasties and the selection of cabinet ministers' in Legislative Studies Quarterly, xli, no. 1 (Feb. 2017), p. 133.

186 Eoghan Ó Raghallaigh, 'Dillon, Myles Patrick', in D.I.B. 
the events of 1916-23. ${ }^{187}$ Moreover, while some of their fathers may have brooded over the 'incomplete' nature of Irish nationhood after 1922, the great majority of their children seem to have been able to overcome whatever personal and political disappointments 1918 represented and integrate themselves into the new Irish state. ${ }^{188}$

In so doing, they did not forget the Ireland that their fathers' generation had worked so hard to achieve. James Dillon, for one, saw his career as the fulfilment of John Dillon's work. ${ }^{189}$ W. A. Redmond was involved in publicly remembering both his father and uncle in the $1920 \mathrm{~s} .{ }^{190}$ The son of one of Parnell's 'faithful few' of the 1890s, Niall Harrington, became president and secretary of the Parnell Commemoration Association and was instrumental in the creation of the Glasnevin memorial to Parnell and the designation of Avondale as a national heritage site. ${ }^{191}$ Tom Kettle's daughter Betty also participated in the commemoration of Parnell's death, while as a young child she raised money for the Irish Nationalist Veterans' Association. ${ }^{192}$ James Nugent succeeded his father as national secretary of the A.O.H. in $1940 .{ }^{193}$ His brother was also a national trustee of the A.O.H., while their sister Kathleen was president of the Ladies Auxiliary of the order. ${ }^{194}$ Denis Gwynn was an early biographer of John Redmond and a member of the committee formed in 1966 to mark the fiftieth anniversary of Tom Kettle's death. ${ }^{195}$

Along with ten other I.P.P. children (Patrick Byrne, Thomas Byrne, James Dillon, Father Shawn Dillon, Sir John L. Esmonde, Mary Kettle, James Nugent, Eugene Sheehy, Honor Crowley and Brian Whitty), Denis Gwynn was involved in the events organised in 1956 to mark the centenary of John Redmond's birth. Dr Anthony Esmonde T.D. successfully lobbied the government to issue a commemorative stamp to mark the occasion. ${ }^{196}$ Speaking during the centenary, James Dillon declared that he was 'proud of my old leader and proud ... to declare my unaltered loyalty and devotion to the ideals in the service of which he spent his life'. ${ }^{197}$ Another child of the I.P.P. (albeit one who had also been a member) who seems to have considered himself 'a proud unrepentant Redmondite' in 1956 was Sir John L. Esmonde who asked,

Could anyone doubt that if the British Government of the day had ... put the Home Rule Act into operation, Ireland would have been spared the troubles and sorrows that she had passed through and that today a united people with a united Government for the whole of Ireland

187 Manning, 'Dillon, James Matthew', in D.I.B.; Manning, James Dillon, p. 3.

188 Reid, 'Between the Redmondite and revolutionary generations', pp 136, 147.

189 Manning, James Dillon, p. 56.

190 Martin O'Donoghue, "The renewal of a pledge of faith"?: "John Redmond days" in the south-east in the 1920s' in History Ireland, xxiii, no. 1 (Jan./Feb. 2015), pp 28-41.

191 Noel Kissane, 'Harrington, Niall Charles', in D.I.B.

192 Irish Independent, 5 Oct. 1937; Freeman's Journal, 13 Nov. 1918.

193 Irish Times, 26 Dec. 1960.

194 Ibid., 4 Jan. 1969; Irish Independent, 19 Dec. 1938.

195 Irish Press, 2 Sept. 1966.

196 Munster Express, 28 Sept. 1956, 11 July 1958; Irish Press, 1 Oct. 1956; Irish Times, 3, 18, 27 Sept. 1956; Irish Examiner, 3, 5 Sept. 1956; Irish Independent, 1 Oct. 1956.

197 Irish Examiner, 1 Oct. 1956. 
would be working side by side in friendship and trust, with her neighbour beyond the Irish Sea? ${ }^{198}$

Notwithstanding the fact that he had been a founding member of Fine Gael, served as a T.D., and almost become a government minister, forty years after the death of the I.P.P., Esmonde still felt a sense of loss for the Ireland that might have been. Whether the other children of nationalist M.P.s who participated in the Redmond anniversary felt the same way (let alone those who did not attend) is unknown, but their coming together in 1956 illustrates both the progress they had made since 1922, as well the continuing relevance of the Redmondite legacy to their lives and careers in an independent Ireland.

In J. G. Farrell's 1970 novel Troubles, the main character, Major Brendan Archer, witnesses an argument between his host (an Anglo-Irish hotelier) and one of his fellow guests, who is described as an old Parnellite. Their argument concerns whose 'voice' the British government should listen to in resolving the on-going War of Independence (southern unionists or constitutional nationalists), with their rival claims turning on the relative sacrifices of their young male supporters during the recent struggle against Germany. The long retreat of the ascendancy is a familiar theme of twentieth-century literature about the years 1916 to 1923, but the fact that Farrell depicted a querulous home ruler seeking sanctuary within the 'big house' highlights another view of these years: that of bewildered Redmondites retreating from the realities of revolutionary Ireland. ${ }^{199}$

As this article has sought to demonstrate, even if this depiction captures something of the difficulties faced by the older generation of home rulers to adjust to the rapidly changing political circumstances of Ireland after 1918, their children were certainly not all either lying in war graves or skulking in 'big houses'. Indeed, their relationship to the pre-war 'Irish establishment', as examined here, suggests that their prospects were always much more dependent on the realisation of home rule in the near future than in the fortunes of the ailing ancien régime of British Ireland. Consequently, their experience of the years between 1916 and 1923 were different to those of the ascendancy. There was undoubtedly a period of uncertainty and confusion during the War of Independence and the early years of the new state, but, with more than a few backward glances, the children of the Irish party entered into the brave new world that emerged after 1922. That they did not merely survive but in many cases (pace Conor Cruise O'Brien) thrive has been one of the main findings of this article. Unlike those who had 'fought for the new Jerusalem of a visionary republic' but ended up disillusioned and feeling like they were on the losing side, what the children of the I.P.P. lost after 1918 should not obscure the fact that many of them were, ultimately, among the winners in the new Ireland. ${ }^{200}$

198 Irish Times, 1 Oct. 1956.

199 J. G. Farrell, Troubles (London, 1970); Brian Donnelly, 'The big house in the recent novel' in Studies, 1xiv, no. 254 (Summer 1975), pp 133-42.

200 Foster, Vivid faces, p. 291. This article resulted from a paper delivered to the Parnell Summer School in 2016. The author would like to thank the school's academic director, William Murphy, and the organising committee for this opportunity. 